\title{
The status and decadal change of glaciers in Bhutan from the 1980s to 2010 based on satellite data
}

\author{
Samjwal Ratna BAJRACHARYA, Sudan Bikash MAHARJAN, Finu SHRESTHA \\ International Centre for Integrated Mountain Development (ICIMOD), Kathmandu, Nepal \\ E-mail: sabajracharya@icimod.org
}

\begin{abstract}
In order to monitor changes in the glaciers in the Bhutan Himalaya, a repeat decadal glacier inventory was carried out from Landsat images of 1977/78 ( 1980), 1990, 2000 and 2010. The base map of glaciers was obtained by the object-based image classification method using the multispectral Landsat images of 2010. This method is used separately to delineate clean-ice and debriscovered glaciers with some manual editing. Glacier polygons of 2000, 1990 and $~ 1980$ were obtained by manual editing on 2010 by separately overlaying respective years. The 2010 inventory shows 885 glaciers with a total area of $\sim 642 \pm 16.1 \mathrm{~km}^{2}$. The glacier area is $1.6 \%$ of the total land cover in Bhutan. The result of a repeat inventory shows $23.3 \pm 0.9 \%$ glacial area loss between $\sim 1980$ and 2010 , with the highest loss $(11.6 \pm 1.2 \%)$ between $\sim 1980$ and 1990 and the lowest $(6.7 \pm 0.1 \%)$ between 2000 and 2010. The trend of glacier area change from the 1980 s to 2010 is $-6.4 \pm 1.6 \%$. Loss of glacier area was mostly observed below $5600 \mathrm{~m}$ a.s.l. and was greater for clean-ice glaciers. The equilibrium-line altitude has shifted upward from $5170 \pm 110 \mathrm{~m}$ a.s.l. to $5350 \pm 150 \mathrm{~m}$ a.s.l. in the years $\sim 1980-2010$.
\end{abstract}

KEYWORDS: glacier mapping, mountain glaciers, remote sensing

\section{INTRODUCTION}

The Himalayan glaciers have retreated remarkably in the past two decades (Fujita and others, 2001; Bajracharya and others, 2007), and area loss rates have accelerated in recent decades due to climate change (Bajracharya and Mool, 2009; Bolch and others, 2012). Although it is still ambiguous which climatic parameter plays the main role in glacier retreat, the current glacier retreat in the Himalaya is due to the combined effect of reduced precipitation and warmer temperature (Ren and others, 2006). There are very few data on the glaciers of Bhutan. Although glacier inventories for most parts of the world have been ingested into the Global Land Ice Measurements from Space (GLIMS) database (Raup and others, 2007) and Randolph Glacier Inventory v.3.0, the glacier outline from the Bhutan region is still incomplete (Arendt and others 2013). The glacier inventory of Bhutan was first prepared by ICIMOD in 2001 based on topographic maps of the 1970s, and estimated a glacier area of $\sim 1317 \mathrm{~km}^{2}$ (Mool and others, $2001 \mathrm{a}, \mathrm{b})$. The glacier area mapped in Bhutan and the adjacent area in 2012 was $\sim 1930 \mathrm{~km}^{2}$ (Rupper and others 2012), which was larger than the ICIMOD estimate in 2001. ICIMOD 2011 (Bajracharya and Shrestha, 2011; Bolch and others, 2012) mapped the glaciers of the Hindu KushHimalayan region, including the Bhutan Himalaya, from Landsat images of $2005 \pm 3$ years and estimated a glacier area of $\sim 642 \mathrm{~km}^{2}$ (based on Bhutan's new national boundary). The Bhutan data are based on late 2008, so there is no difference in area with the present inventory of 2010.

This study will help us to understand the trend of glacier change in the decades from $~ 1980$ to 2010 and the status of glaciers in Bhutan in the coming years.

\section{STUDY AREA AND DATA}

\section{Study area}

Bhutan is a small, landlocked and mountainous country located at $26^{\circ} 45^{\prime}-28^{\circ} 10^{\prime} \mathrm{N}, 88^{\circ} 45^{\prime}-92^{\circ} 10^{\prime} \mathrm{E}$ on the southern slopes of the eastern Himalaya. The Amochu (Torsa), Wangchu, Punatsangchu (Sankosh), Manaschu and Nyere Amachu are the main rivers of Bhutan and tributaries of the Brahmaputra River in India. All the rivers except the Amochu and Nyere Amachu are glacier-fed in Bhutan.

\section{Satellite images}

Two Landsat images cover the total area of the Bhutan Himalaya. Landsat images of 1977/78 ( 1980), 1990, 2000 and 2010 with least snow and no cloud cover were obtained from the United States Geological Survey (USGS). The suitability of a particular image depends on the presence or absence of seasonal snow, cloud cover and the date of acquisition. The images for $\sim 1980$ had a smaller choice and somewhat more snow cover than those for the other years. The snow cover is eliminated by comparing with topographic maps and images of 1975/76.

\section{METHODS}

The glacier mapping from automated multispectral classification of optical satellite data in combination with a digital elevation model (DEM) is a well-established procedure (Paul and Kääb, 2005; Bhambri and Bolch, 2009; Paul and Andreassen, 2009; Racoviteanu and others, 2009; Bolch and others, 2010; Frey and Paul, 2012). A semi-automatic methodology was used separately for delineation of cleanice $(\mathrm{Cl})$ and debris-covered (DC) glaciers using an objectbased image classification (OBIC) approach (Bajracharya and Shrestha, 2011). The image classification was processed in eCognition Developer software. Primarily, the 2010 image was segmented using multi-resolution segmentation which creates the image object based upon spectral, shape, orientational and textural characteristics. The image objects are a group of pixels having homogeneous characteristics. These image objects were classified by developing rule sets based on spectral and spatial characteristics. The rule set 
used the mean value of the defined areas instead of individual pixel value. It is developed separately for classification of $\mathrm{Cl}$ and DC glaciers.

All the classified $\mathrm{Cl}$ and DC image objects were merged and the products were exported to an .shp file. The glacier polygons were manually separated into the individual glaciers based on the hydrological catchments by overlaying on images and hillshade generated from the DEM in the ArcGIS environment. Further, the glacier polygons of 2010 were overlaid on the Landsat images of 2000, 1990 and 1980 to generate the glacier outlines manually for the respective years.

\section{Mapping of clean-ice glacier}

The identification of $\mathrm{Cl}$ glaciers relied mainly on the normalized difference snow index (NDSI = [VIS (red, TM3) SWIR (TM5)]/[VIS + SWIR], where VIS is the visible band, TM is the Landsat Thematic Mapper and SWIR is the shortwave infrared band), which is often used to discriminate between snow, soil, rocks and cloud cover. Besides the ability to map snow in rough topography (Silverio and Jaquet, 2005), this index provides a good contrast between bare ice and its surroundings at the glacier tongue (Hall and others, 2003). The $\mathrm{Cl}$ glaciers were mapped by applying NDSI threshold values (Silverio and Jaquet, 2005). Typically, NDSI values of $\mathrm{Cl}$ glaciers in Landsat images lie between 0.5 and 0.7 (Hendriks and others 2007), differing from image to image due to illumination differences. We used the NDSI threshold value $\geq 0.5$ to capture the $\mathrm{Cl}$ segments based on the histogram, visual inspection and sampling values. Even using the precise threshold value, the captured $\mathrm{Cl}$ image objects are either over- or less captured. We prefer over-capture so as not to miss the glacier image objects. The over-captured image objects comprise shadow, water bodies, vegetation, bare rock and debris, which were removed by performing different filters including the normalized difference vegetation index (NDVI $=[N I R$ (TM4)-VIS (TM3)]/[NIR + VIS], where NIR is the nearinfrared band) threshold value of $\geq 0.34$ for vegetation, a land and water mask $(\mathrm{LWM}=([\mathrm{SWIR} / \mathrm{VIS}]+0.0001) \times 100)$ threshold value of $\geq 31.5$ for water bodies, and mean hue for shadow. Further, slope with a threshold value $>60^{\circ}$ and elevation $<4600 \mathrm{~m}$ a.s.l. was applied to remove the misclassified $\mathrm{Cl}$ image objects.

\section{Mapping of debris-covered glacier}

Once the $\mathrm{Cl}$ glaciers were mapped, the DC glaciers were captured from the remaining unclassified image objects using a slope threshold value of $<25^{\circ}$ and elevation between 6000 and 3000 ma.s.l. depending upon the locality. Paul and others (2004) followed a semi-automated approach to map a DC glacier using the slope gradient. Capturing of DC glaciers is complicated by effects from the surroundings (Paul and others, 2004; Bolch and Kamp, 2006; Bolch and others, 2007; Racoviteanu and others, 2009). Further, the misclassified image objects were then removed using the threshold values of NDVI (>0.3), NDSI $(\geq 0.005)$ and LWM (50-115.8) for vegetation, snow and land and water bodies respectively.

This process satisfactorily delineates the outline of DC glaciers which were then finalized by manual editing at a scale of $1: 20000$ by draping over high-resolution images from Google Earth. Special attention was given to defining the outline and snout of the glaciers.

\section{Equilibrium-line altitude}

The snowline altitude in a glacier measured after the summer is known as the equilibrium-line altitude (ELA; Rabatel and others, 2005, 2013). The images of no cloud and least snow cover from September to early November were selected to compute the ELA. The image bands TM5 (SWIR), TM4 (NIR) and TM2 (green) are the most appropriate band combination in red, green, blue (RGB) to identify the limit between snow and ice (Rabatel and others, 2012). The ELAs were drawn from at least 10-20 points of snow and ice boundary for each glacier. The average ELA is computed from the Shuttle Radar Topography Mission (SRTM) DEM. The ELAs of 32 valley glaciers were delineated manually for all decades.

An uncertainty of each ELA was calculated as the standard deviation of altitude of all the points of snowline in each glacier.

\section{Accuracy}

The accuracy of the glacier outlines depends, typically, on the resolution of the images used, seasonal snow, shadow and the contrast between the glacier and its surroundings (DeBeer and Sharp, 2007). The most accurate way to assess glacier outlines is to use high-resolution imagery (Paul and others, 2013), but such data were not available for our study region. Hence, the available medium-resolution Landsat images with least snow and no cloud cover were used. To minimize the uncertainties, the OBIC-derived glacier image objects were refined by editing manually with reference to the high-resolution images available from Google. The delineated glacier boundaries were affected by various types of obscurities, and maximum offset of the boundary was assigned to each type of obscurity, which could not be greater than half of the image resolution (i.e. $\pm 15 \mathrm{~m}$ in TM and Enhanced TM Plus (ETM+) and $\pm 40 \mathrm{~m}$ in Multispectral Scanner (MSS)). Hence, the uncertainties of the glacier area were estimated by variation of each glacier area from the glacier polygon (depending on projection parameter) and area calculated on pixel base (depends on image resolution). The pixel-based area is calculated as the product of the total number of pixels bounded by the glacier boundary and the image resolution.

The total uncertainty (error) of glacier area was calculated as

$$
\mathrm{RMSE}=\sqrt{\frac{\sum_{i=1}^{n}\left(\mathrm{a}_{i}-\hat{a}_{i}\right)^{2}}{n}}
$$

where $a_{i}$ is the area of glacier from the glacier polygon and $\hat{a}_{i}$ is the area of glacier calculated on the pixel base.

The uncertainty of glacier area in the present study is variously $3.4 \%, 2.5 \%, 2.4 \%$ and $2.5 \%$ for the years $\sim 1980$, 1990, 2000 and 2010 respectively. These mapping uncertainties are within the range of previous estimates of $\sim 3 \%$ (Paul and others, 2002; Bolch and others, 2010; Frey and others, 2012).

\section{RESULTS}

A total of 885 glaciers were mapped from the images of 2010 , with an area of $642 \pm 16.1 \mathrm{~km}^{2}(1.6 \%$ of Bhutan's total land) (Table 1; Fig. 1). The Punatsangchu basin has the highest number of glaciers (436) and glacier area $\left(361.6 \pm 9.3 \mathrm{~km}^{2}\right)$, and the Wangchu basin has the lowest number of glaciers (56) and glacier area $\left(32.8 \pm 0.7 \mathrm{~km}^{2}\right)$. 
Table 1. Number and area of clean-ice (Cl) and debris-covered (DC) glaciers and largest glaciers in 1980, 1990, 2000 and 2010 in the basins and sub-basins of Bhutan. All the glaciers were mapped with $\mathrm{Cl}$, some of which was DC except in Thimchu and Dangmechu sub-basins

\begin{tabular}{|c|c|c|c|c|c|c|c|c|}
\hline \multirow[t]{3}{*}{ Year } & \multirow[t]{3}{*}{ Basin } & \multirow[t]{3}{*}{ Sub-basin } & \multicolumn{2}{|c|}{ Number of glaciers } & \multicolumn{4}{|c|}{ Glacier area } \\
\hline & & & $\mathrm{Cl}$ & DC & $\mathrm{Cl}$ & DC & Total & Largest glacier \\
\hline & & & & & $\mathrm{km}^{2}$ & $\mathrm{~km}^{2}$ & $\mathrm{~km}^{2}$ & $\mathrm{~km}^{2}$ \\
\hline \multirow[t]{12}{*}{ 1980 } & \multirow[t]{3}{*}{ Wangchu } & Thimchu & 17 & 0 & $6.9 \pm 0.4$ & $0.0 \pm 0.0$ & $6.9 \pm 0.4$ & 1.7 \\
\hline & & Pachu & 34 & 2 & $31.3 \pm 1.0$ & $5.0 \pm 0.0$ & $36.3 \pm 1.1$ & 9.4 \\
\hline & & Subtotal & 51 & 2 & $38.2 \pm 1.7$ & $5.0 \pm 0.0$ & $43.2 \pm 2.0$ & 9.4 \\
\hline & \multirow[t]{3}{*}{ Punatsangchu } & Mochu & 150 & 15 & $146.1 \pm 4.4$ & $6.8 \pm 0.2$ & $152.9 \pm 4.6$ & 11.9 \\
\hline & & Phochu & 209 & 15 & $266.2 \pm 7.7$ & $43.0 \pm 0.7$ & $309.2 \pm 8.9$ & 48.6 \\
\hline & & Subtotal & 359 & 30 & $412.3 \pm 12.2$ & $49.8 \pm 1.1$ & $462.1 \pm 13.6$ & 48.6 \\
\hline & \multirow[t]{5}{*}{ Manaschu } & Mangdechu & 121 & 4 & $120.2 \pm 4.5$ & $13.8 \pm 0.3$ & $134.0 \pm 5.0$ & 25.7 \\
\hline & & Chamkharchu & 117 & 5 & $91.1 \pm 3.4$ & $8.5 \pm 0.2$ & $99.6 \pm 3.7$ & 20.0 \\
\hline & & Kurichu & 88 & 6 & $76.3 \pm 3.0$ & $3.1 \pm 0.0$ & $79.5 \pm 3.2$ & 14.2 \\
\hline & & Dangmechu & 35 & 0 & $19.2 \pm 0.6$ & $0.0 \pm 0.0$ & $19.2 \pm 0.6$ & 2.4 \\
\hline & & Subtotal & 361 & 15 & $306.9 \pm 11.4$ & $25.5 \pm 0.5$ & $332.3 \pm 12.4$ & 25.7 \\
\hline & Total & & 771 & 47 & $757.4 \pm 26.1$ & $80.2 \pm \mathbf{1 . 6}$ & $\mathbf{8 3 7 . 6} \pm \mathbf{2 8 . 8}$ & 48.6 \\
\hline \multirow[t]{12}{*}{1990} & \multirow[t]{3}{*}{ Wangchu } & Thimchu & 18 & 0 & $6.3 \pm 0.2$ & $0.0 \pm 0.0$ & $6.3 \pm 0.2$ & 1.7 \\
\hline & & Pachu & 38 & 2 & $26.3 \pm 0.6$ & $5.2 \pm 0.0$ & $31.5 \pm 0.8$ & 7.9 \\
\hline & & Subtotal & 56 & 2 & $32.6 \pm 0.9$ & $5.2 \pm 0.01$ & $37.8 \pm 1.0$ & 7.9 \\
\hline & \multirow[t]{3}{*}{ Punatsangchu } & Mochu & 162 & 14 & $127.9 \pm 2.3$ & $7.9 \pm 0.1$ & $135.8 \pm 2.4$ & 11.3 \\
\hline & & Phochu & 235 & 15 & $237.1 \pm 6.5$ & $45.7 \pm 0.4$ & $282.8 \pm 7.8$ & 44.1 \\
\hline & & Subtotal & 397 & 29 & $365.0 \pm 8.7$ & $53.6 \pm 0.4$ & $418.6 \pm 10.0$ & 44.1 \\
\hline & \multirow[t]{5}{*}{ Manas } & Mangdechu & 138 & 5 & $105.3 \pm 2.3$ & $15.3 \pm 049$ & $120.6 \pm 2.6$ & 23.5 \\
\hline & & Chamkharchu & 118 & 6 & $76.4 \pm 1.3$ & $8.9 \pm 0.1$ & $85.3 \pm 1.5$ & 17.8 \\
\hline & & Kurichu & 95 & 6 & $67.8 \pm 1.3$ & $3.2 \pm 0.0$ & $71.0 \pm 1.3$ & 13.6 \\
\hline & & Dangmechu & 26 & 0 & $7.5 \pm 0.2$ & $0.0 \pm 0.0$ & $7.5 \pm 0.2$ & 2.0 \\
\hline & & Subtotal & 377 & 17 & $257.0 \pm 5.2$ & $27.4 \pm 0.4$ & $284.4 \pm 5.7$ & 23.5 \\
\hline & Total & & 830 & 48 & $654.6 \pm 14.7$ & $\mathbf{8 6 . 2} \pm \mathbf{1 . 0}$ & $740.7 \pm 16.7$ & 44.1 \\
\hline \multirow[t]{12}{*}{2000} & \multirow[t]{3}{*}{ Wangchu } & Thimchu & 18 & 0 & $5.7 \pm 0.2$ & $0.0 \pm 0.0$ & $5.7 \pm 0.2$ & 1.6 \\
\hline & & Pachu & 39 & 2 & $23.8 \pm 0.7$ & $5.5 \pm 0.0$ & $29.3 \pm 0.9$ & 7.5 \\
\hline & & Subtotal & 57 & 2 & $29.5 \pm 0.9$ & $5.5 \pm 0.0$ & $35.0 \pm 1.0$ & 7.5 \\
\hline & \multirow[t]{3}{*}{ Punatsangchu } & Mochu & 173 & 15 & $115.1 \pm 2.2$ & $9.4 \pm 0.1$ & $124.4 \pm 2.4$ & 10.8 \\
\hline & & Phochu & 255 & 15 & $217.8 \pm 5.5$ & $46.2 \pm 0.3$ & $264.0 \pm 6.6$ & 37.3 \\
\hline & & Subtotal & 428 & 30 & $332.9 \pm 7.6$ & $55.5 \pm 0.3$ & $388.4 \pm 8.9$ & 37.3 \\
\hline & \multirow[t]{5}{*}{ Manas } & Mangdechu & 144 & 5 & $100.1 \pm 2.1$ & $15.5 \pm 0.3$ & $115.6 \pm 3.0$ & 20.9 \\
\hline & & Chamkharchu & 125 & 7 & $68.8 \pm 1.6$ & $9.9 \pm 0.1$ & $78.7 \pm 1.9$ & 17.2 \\
\hline & & Kurichu & 96 & 6 & $60.4 \pm 1.3$ & $3.7 \pm 0.0$ & $64.1 \pm 1.4$ & 13.2 \\
\hline & & Dangmechu & 24 & 0 & $6.4 \pm 0.2$ & $0.0 \pm 0.0$ & $6.4 \pm 0.2$ & 1.6 \\
\hline & & Subtotal & 389 & 18 & $235.7 \pm 5.7$ & $29.1 \pm 0.4$ & $264.8 \pm 6.4$ & 20.9 \\
\hline & Total & & 874 & 50 & $598.2 \pm 14.3$ & $\mathbf{9 0 . 0} \pm \mathbf{0 . 8}$ & $\mathbf{6 8 8 . 2} \pm \mathbf{1 6 . 5}$ & 37.3 \\
\hline \multirow[t]{12}{*}{2010} & \multirow[t]{3}{*}{ Wangchu } & Thimchu & 19 & 0 & $5.2 \pm 0.1$ & $0.0 \pm 0.0$ & $5.2 \pm 0.1$ & 1.5 \\
\hline & & Pachu & 37 & 2 & $22.2 \pm 0.4$ & $5.4 \pm 0.0$ & $27.6 \pm 0.5$ & 7.2 \\
\hline & & Subtotal & 56 & 2 & $27.4 \pm 0.6$ & $5.4 \pm 0.0$ & $32.8 \pm 0.7$ & 7.2 \\
\hline & Punatsangchu & Mochu & 180 & 15 & $103.8 \pm 2.9$ & $9.9 \pm 0.1$ & $113.7 \pm 3.1$ & 10.4 \\
\hline & & Phochu & 256 & 15 & $201.1 \pm 4.9$ & $46.9 \pm 0.2$ & $247.9 \pm 6.1$ & 36.6 \\
\hline & & Subtotal & 436 & 30 & $304.8 \pm 7.9$ & $56.8 \pm 0.4$ & $361.6 \pm 9.3$ & 36.6 \\
\hline & Manas & Mangdechu & 150 & 5 & $91.9 \pm 2.5$ & $15.8 \pm 0.1$ & $107.8 \pm 3.05$ & 20.3 \\
\hline & & Chamkharchu & 125 & 7 & $62.1 \pm 1.5$ & $9.8 \pm 0.1$ & $71.9 \pm 1.8$ & 15.6 \\
\hline & & Kurichu & 96 & 6 & $57.8 \pm 1.3$ & $3.6 \pm 0.0$ & $61.4 \pm 1.4$ & 12.5 \\
\hline & & Dangmechu & 22 & 0 & $6.7 \pm 0.1$ & $0.0 \pm 0.0$ & $6.7 \pm 0.2$ & 1.5 \\
\hline & & Subtotal & 393 & 18 & $218.5 \pm 5.4$ & $29.2 \pm 0.3$ & $247.7 \pm 6.2$ & 20.3 \\
\hline & Total & & 885 & 50 & $550.7 \pm 13.8$ & $\mathbf{9 1 . 4} \pm \mathbf{0 . 7}$ & $642.1 \pm 16.1$ & 36.6 \\
\hline
\end{tabular}

The largest glacier is G090161E28125N in the Phochu subbasin of Punatsangchu basin with an area of $36 \mathrm{~km}^{2}$. The glacier elevation ranges from $7230 \mathrm{~m}$ a.s.l. (in the Manaschu basin) to $4050 \mathrm{~m}$ a.s.I. (in the Punatsangchu basin).

\section{Decadal glacier change}

Overall, the number of glaciers shows an increasing trend, whereas the glacier area shows a decreasing trend in the decades from $\sim 1980$ to 2010 (Fig. 2).

The number of glaciers increased by $7 \%, 5.3 \%$ and $1.2 \%$ during the decades $~ 1980-90,1990-2000$ and 2000-10 respectively, with an overall increase of $14.8 \%$ in 30 years ( 1980 to 2010) (Table 1). The glacier area decreased by $11.6 \pm 1.2 \%, 7.1 \pm 0.1 \%$ and $6.7 \pm 0.1 \%$ during the decades 1980-90, 1990-2000 and 2000-10 respectively, with an overall decrease of $23.3 \pm 0.9 \%$ in 30 years (Tables 2 and 3 ). The average glacier area in $\sim 1980$ was $>1 \mathrm{~km}^{2}$ but decreased to $<1 \mathrm{~km}^{2}$ in consecutive decades due to an increase in the number of glaciers and a decrease in glacier area. The increase in number with concomitant loss of glacier area indicates fragmentation of existing glaciers due to shrinking rather than the development of new glaciers. 


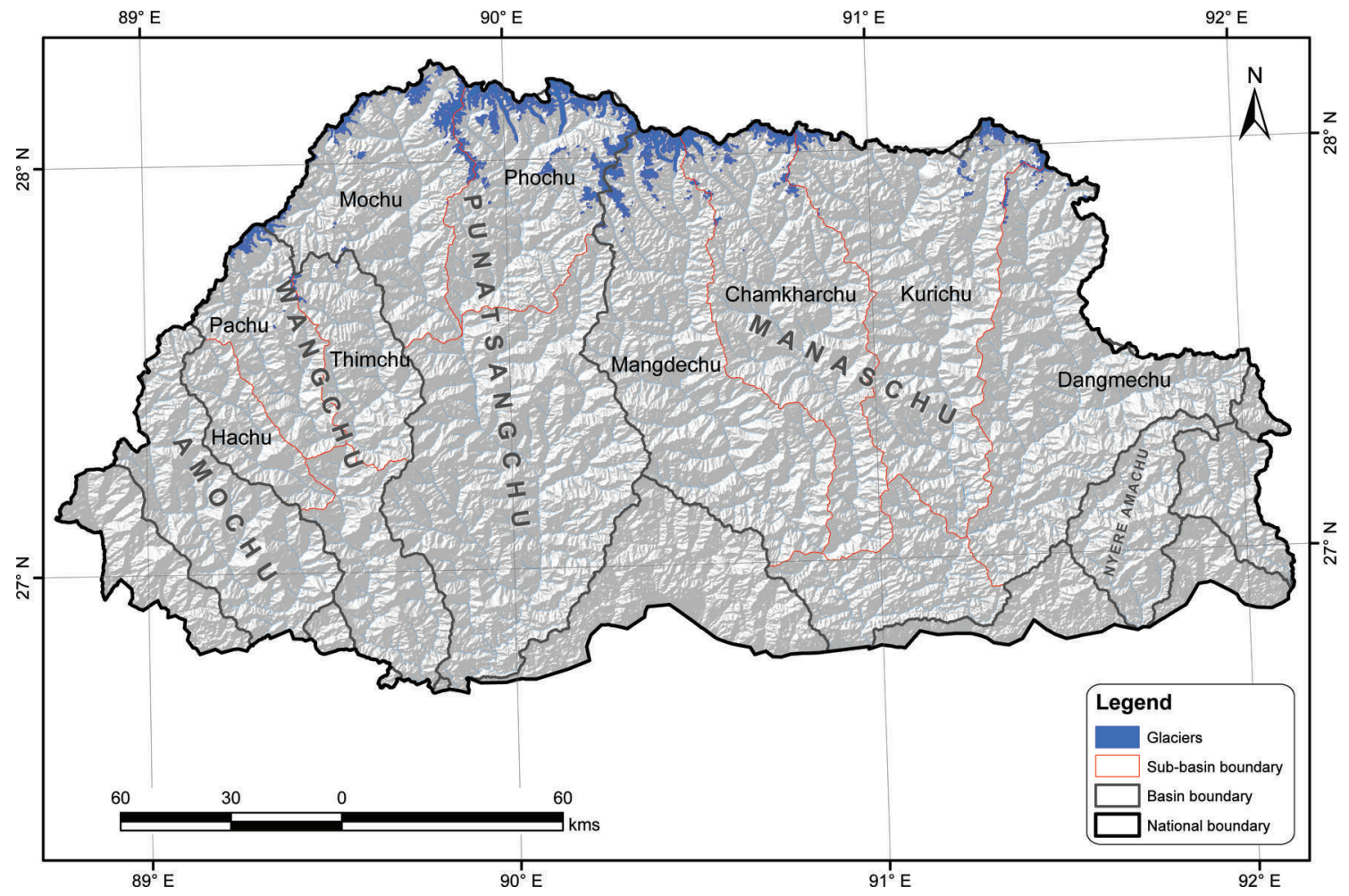

Fig. 1. Distribution of glaciers in the sub-basins of Bhutan in 2010. (The boundary of Bhutan is provided by National Land Commission, Bhutan, 2007.)

Nonetheless glacier number slightly decreased in 2010 due to the dissolution of glaciers on steep slopes. As an example, changes in glacier boundaries over time in the Landsat images for the Lunana area are shown in Figure 3.

The values for the area and change in area of $\mathrm{Cl}$ and DC glaciers from $\sim 1980$ to 2010 are summarized in Table 2. In 2010 , DC glaciers comprised $\sim 14.23 \%$ of total glacier area. This value is $4.53 \%$ higher than the average value for the Hindu Kush-Himalayan region (Bajracharya and Shrestha, 2011). The DC glaciers were only identified at elevations below $5548 \mathrm{~m}$ a.s.I., which is the region where glacier area loss is highest (Fig. 4). Additional DC glaciers were also exposed due to the loss of $\mathrm{Cl}$ glaciers in the lower valleys. Once the lake was formed in the DC glaciers, the glaciers retreated markedly, as observed in lakes such as Imja and Dig Tsho in Nepal, and Luggye, Raphstreng, Thorthormi and
Tarina in Bhutan (Bajracharya and others, 2007). In all decades, the area of $\mathrm{Cl}$ glaciers decreased, whereas the area of DC glaciers increased but by a much smaller amount. Overall, from $\sim 1980$ to $2010, \mathrm{Cl}$ glacier area decreased by $27.3 \pm 0.9 \%\left(206.6 \mathrm{~km}^{2}\right)$ and DC glacier area increased by $13.9 \pm 1.2 \%\left(11.1 \mathrm{~km}^{2}\right)$.

The linear regression trend analysis of the decadal glacier area change is statistically significant at the 95\% confidence level with $p$-value 0.017 . The trend of glacier area change per decade from the $\sim 1980$ s to 2010 is $-6.39 \pm 1.6 \%$ (Fig. 2).

\section{Decadal glacier area change in different elevation zones}

Glaciers mapped in Bhutan were at elevations ranging from 7300 to 3940 ma.s.I., with $>60 \%$ of the glacier area

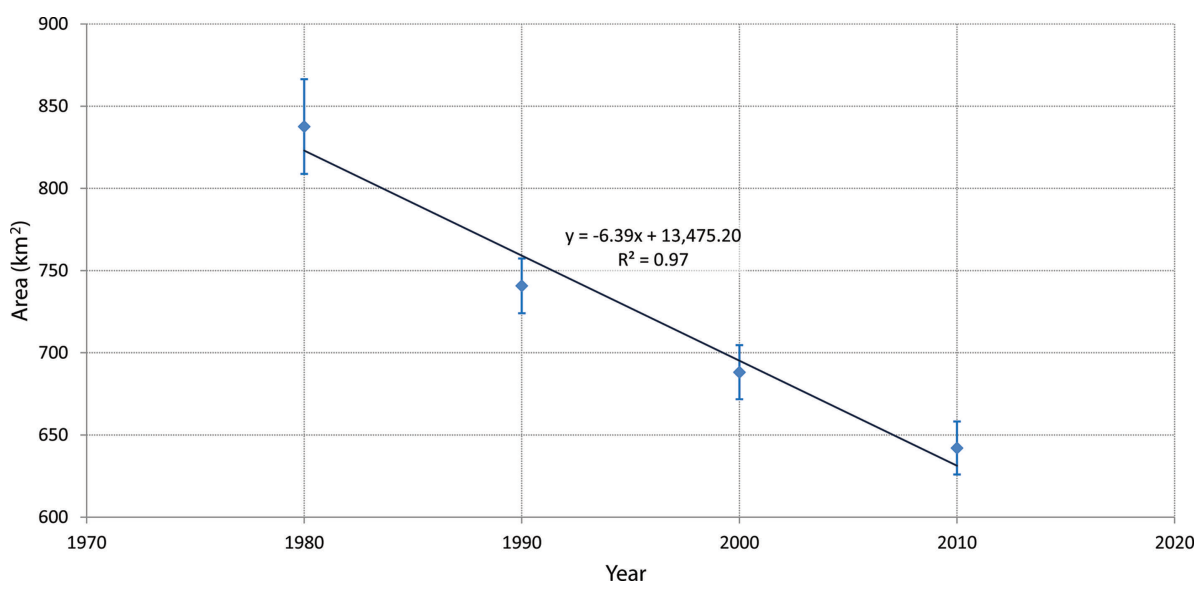

Fig. 2. Status of glacier area in $1980,1990,2000$ and 2010 and its trend. Blue diamonds represent the glacier area, vertical bars represent the error and the diagonal line indicates the trend of the glacier area change. 
Table 2. Decadal Cl and DC glacier area change from 1980 to 2010

\begin{tabular}{|c|c|c|c|c|c|c|}
\hline \multirow[t]{3}{*}{ Year } & \multicolumn{3}{|c|}{ Glacier area } & \multicolumn{3}{|c|}{ Change in glacier area } \\
\hline & $\mathrm{Cl}$ & $\mathrm{DC}$ & Total & $\mathrm{Cl}$ & DC & Total \\
\hline & $\mathrm{km}^{2}$ & $\mathrm{~km}^{2}$ & $\mathrm{~km}^{2}$ & $\%$ & $\%$ & $\%$ \\
\hline$\sim 1980$ & $757.4 \pm 26.05$ & $80.2 \pm 1.61$ & $837.6 \pm 28.81$ & & & \\
\hline 1990 & $654.6 \pm 14.74$ & $86.2 \pm 0.96$ & $740.7 \pm 16.67$ & $-13.6 \pm 1.2$ & $7.5 \pm 0.9$ & $-11.6 \pm 1.2$ \\
\hline 2000 & $598.2 \pm 14.3$ & $90 \pm 0.79$ & $688.2 \pm 16.45$ & $-8.6 \pm 0.1$ & $4.4 \pm 0.2$ & $-7.1 \pm 0.1$ \\
\hline 2010 & $550.7 \pm 13.83$ & $91.4 \pm 0.71$ & $642.1 \pm 16.12$ & $-7.9 \pm 0.1$ & $1.6 \pm 0.1$ & $-6.7 \pm 0.1$ \\
\hline 〜 1980-2010 & & & & $-27.3 \pm 0.9$ & $13.9 \pm 1.2$ & $-23.3 \pm 0.9$ \\
\hline
\end{tabular}

distributed at elevations of 5600-5000 ma.s.l. (Fig. 4). The hypsography of $\sim 1980,1990,2000$ and 2010 shows that the glacier area decreased at 6400-5700, 5500-5000 and 4600-4400 ma.s.l. (Table 3; Fig. 4), with the significant area decrease at 5500 and $5200 \mathrm{~m}$ a.s.l. This indicates that glaciers with median elevations closer to their maximum elevations are losing more area (Racoviteanu and others, 2008). A steady decline of glacier area observed at 6400-5700 ma.s.l. is mainly due to the disappearance of ice on steep slopes, which are shown in Figure 3. Similarly, at 5200-4600 ma.s.I., DC glacier area remained more or less unchanged.

Between 4600 and $4400 \mathrm{~m}$ a.s.I., the distinct change in glacier area is mainly due to formation of new glacial lakes and expansion of existing glacial lakes at the snout of DC glaciers. This shows DC glaciers in contact with a lake are receding at a faster rate than $\mathrm{Cl}$ glaciers in the region. Moreover, Figure 3 shows glacier melt increased rapidly in the period $\sim 1980-90$, followed by a period of less melting from 1990 to 2010. In addition, no massive loss of glacier area is found in the period 2000-10. Over the 30 year period, the loss of glacier area has been uniform across the region. The analysis of 32 valley glaciers shows the ELA has been shifted upward from $5170 \pm 110$ ma.s.l. to $5350 \pm$ $150 \mathrm{~m}$ a.s.I. in 30 years. The ELA was mapped at $5260 \pm 100$ and $5300 \pm 110 \mathrm{ma.s.l}$. in 1990 and 2000 respectively. These ELA results agree well with the ELA from a set of eight selected glaciers that lies at $\sim 5280 \pm 125 \mathrm{~m}$ a.s.l. in northwest Bhutan (Meyer and others, 2009).

\section{DISCUSSION}

The availability of archived Landsat images has made it possible to analyze decadal glacier changes from the 1980s to the present. The repeat inventory of glaciers was carried out for all four decades separately. The Landsat MSS images were used for 1977/78, TM for 1990 and 2000 and ETM+ for 2010. The MSS images are of $79 \mathrm{~m}$ resolution and the TM and ETM+ images are of $30 \mathrm{~m}$ resolution. Several MSS images with suitable conditions are available for mapping the glacier terminus (Vohra, 2010), but the available MSS images of $1977 / 78$ had more snow coverage than those for the TM and ETM+ images. The snow cover in Landsat MSS of $1977 / 78$ was eliminated by comparing with topographic maps and Landsat images of 1975/76.

The 2010 glacier extent was generated using the OBIC method with some manual editing. Change detection in the remaining decades was produced by editing the base map (2010) manually by draping on respective years' images. The delineation of glaciers via manual editing showed certain impacts on the areas of the individual glaciers and subsequently on the analyses (Beedle and others, 2008). In this study, $\sim 2 \%$ loss of glacier area was rectified while smoothing the glacier polygons. For $\mathrm{Cl}$ glaciers and partly DC glaciers, an uncertainty of \pm 1 pixel and \pm 2 pixels respectively was assigned for the outline position (Frey and Paul, 2012). This study observed that loss in glacier area was high $(23.3 \pm 0.9 \%)$ between $\sim 1980$ and 2010 . Loss as high as $\sim 38 \%$ was found on glaciers smaller than $1 \mathrm{~km}^{2}$ in the Himachal Himalaya from 1962 to 2004 (Kulkarni and others 2007).

The increase in the number of glaciers over the decades has affirmed the shrinking and fragmentation of glaciers, which were also reported from the Indian Himalaya (Kulkarni and others, 2007; Basnett and others, 2013) and Nepal Himalaya (Bajracharya and others, 2007). The presence of snow, and the resultant loss in the clarity of glacier boundaries, have contributed somewhat to the increase in glacier area, especially for $\sim 1980$ to 1990 . The changes in the number of glaciers were mainly found among smaller glacier size classes, which contribute a relatively small amount to the total glacier area. The glacier area loss rate is

Table 3. Decadal glacier loss in different elevation zones in Bhutan

\begin{tabular}{|c|c|c|c|c|c|c|c|c|}
\hline \multirow[t]{2}{*}{ Elevation range } & \multicolumn{4}{|c|}{ Glacier area } & \multicolumn{4}{|c|}{ Glacier area loss } \\
\hline & $\sim 1980$ & 1990 & 2000 & 2010 & 〜1980-90 & 1990-2000 & 2000-10 & 1980-2010 \\
\hline ma.s.l. & $\mathrm{km}^{2}$ & $\mathrm{~km}^{2}$ & $\mathrm{~km}^{2}$ & $\mathrm{~km}^{2}$ & $\%$ & $\%$ & $\%$ & $\%$ \\
\hline$<5000$ & $132.5 \pm 16.1$ & $115 \pm 19.8$ & $106.3 \pm 16.5$ & $101.6 \pm 13.2$ & $13.2 \pm 5$ & $7.5 \pm 1.7$ & $4.4 \pm 2.6$ & $23.3 \pm 0.8$ \\
\hline $5000-5600$ & $527.1 \pm 11.6$ & $477.5 \pm 12.4$ & $438.2 \pm 4.8$ & $405.4 \pm 16.5$ & $9.4 \pm 0.4$ & $8.2 \pm 1.5$ & $7.5 \pm 3$ & $23.1 \pm 1.9$ \\
\hline Total & $837.6 \pm 28.8$ & $740.7 \pm 16.7$ & $688.2 \pm 16.4$ & $642.1 \pm 16.12$ & $11.6 \pm 1.2$ & $7.1 \pm 0.1$ & $6.7 \pm 0.1$ & $23.3 \pm 0.9$ \\
\hline
\end{tabular}




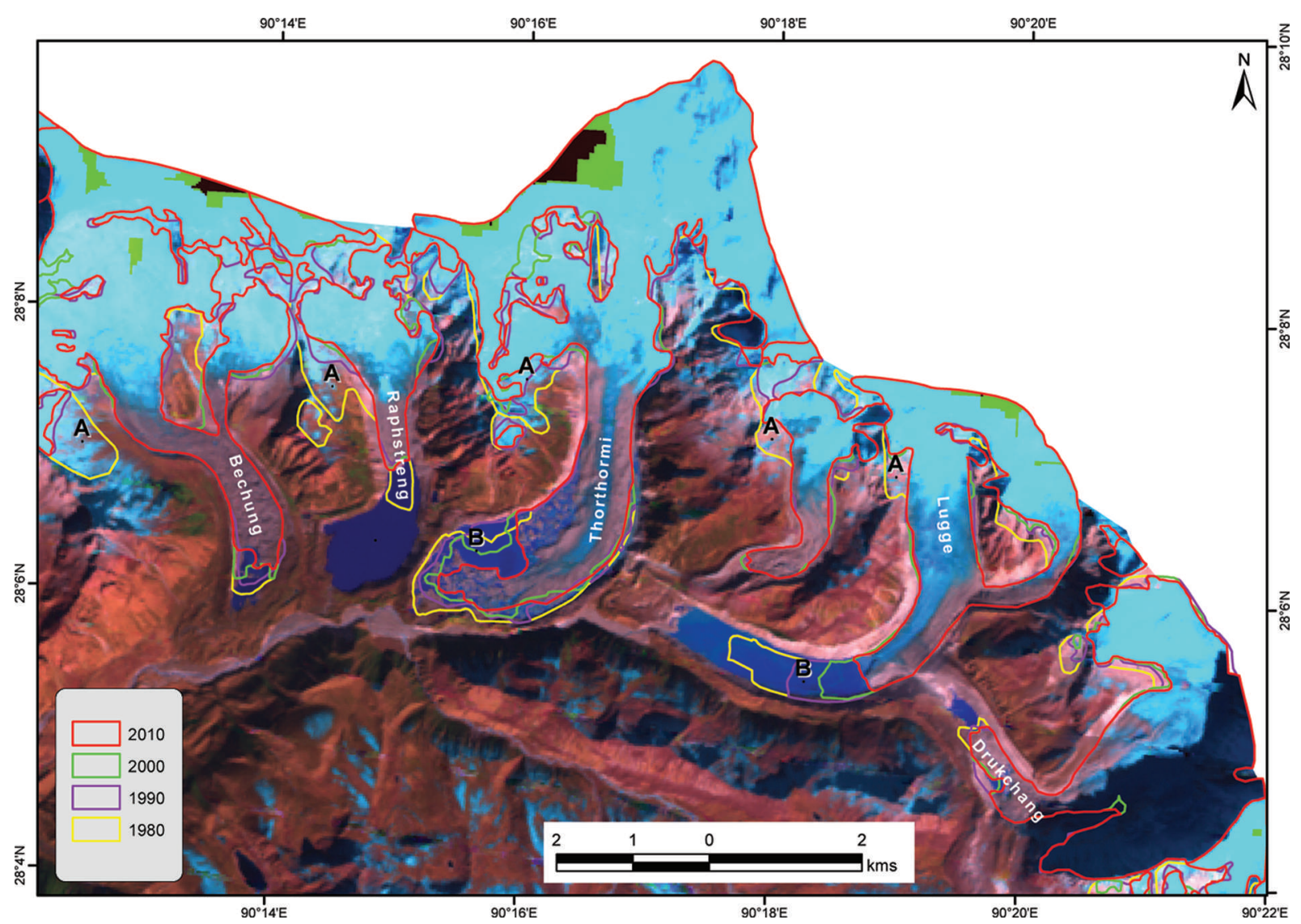

Fig. 3. The change in glacier boundaries from $\sim 1980$ to 2010 in the Lunana area of Bhutan. There was a strong area loss between $\sim 1980$ and 1990. The background image is Landsat ETM+ of 2010 after SLC off gap filled. The distinct ice mass disappearance between 1980 and 1990 is at the examples (A) at the steep slopes and (B) in the lake area.

mostly influenced by glacier size (Bolch and others, 2010). The long valley glaciers associated with glacial lakes have, for the most part, retreated markedly in the past few decades. Expansion of glacier lakes from glacier fluctuation has been reported from north Bhutan (Fujita, 2008; Komori,
2008). The acceleration in glacier recession has been reflected in the Khumbu Himalaya of Nepal (Bolch and others, 2008). The DC glacier area increased in 1990 and 2000, possibly due to the melting of $\mathrm{Cl}$ surfaces resulting in the exposure of debris area. The increased DC glacier area

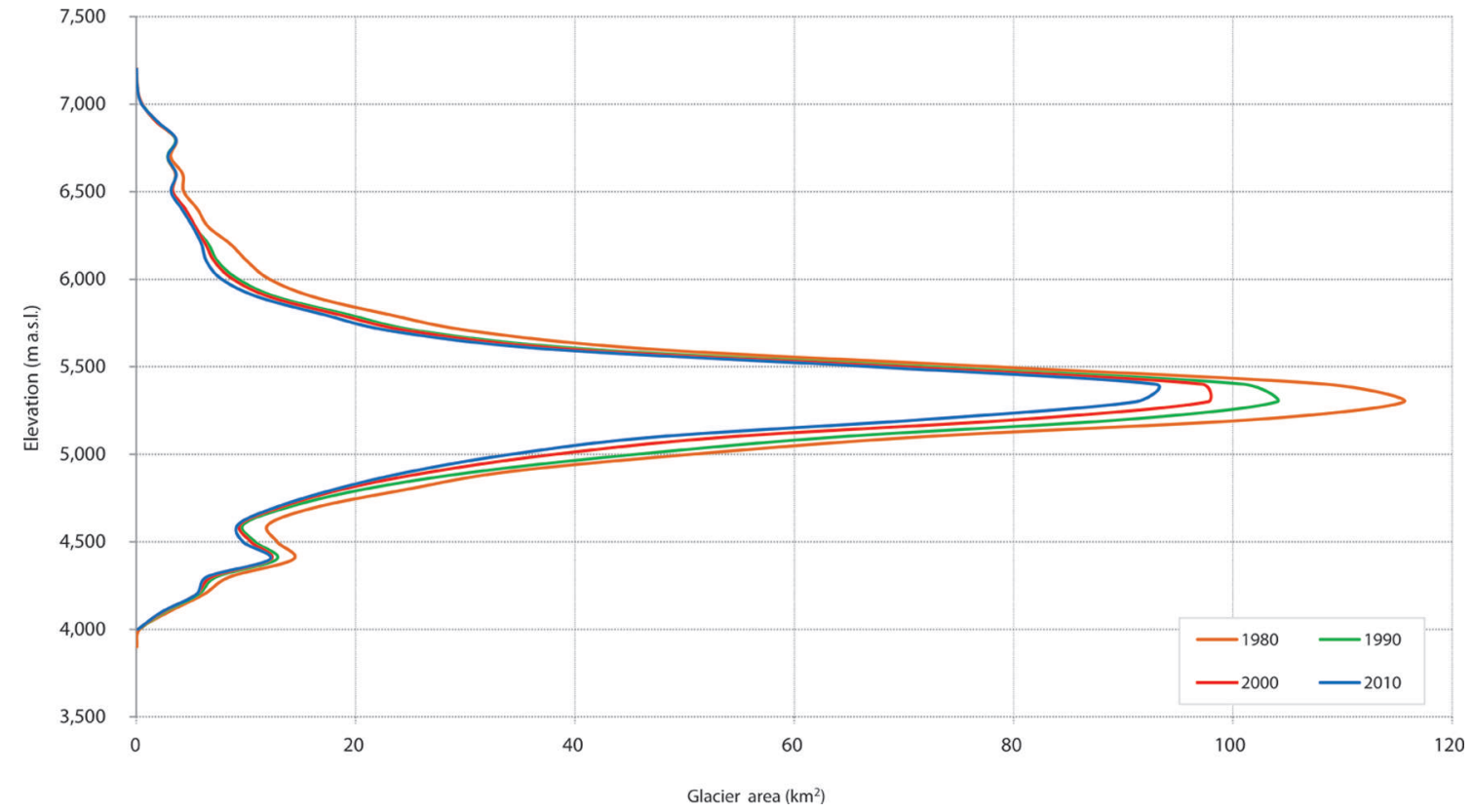

Fig. 4. Hypsography of all glaciers of Bhutan in 1980, 1990, 2000 and 2010. 
during four periods also confirmed the melting of $\mathrm{Cl}$ glaciers. However, the DC glaciers with lake at the snout showed faster recession due to the expansion of lakes or formation of supraglacial lakes.

The area-altitude distribution provides insight into glacier interaction within different elevation zones. Glaciers that extend to low elevations showed a distinct change in size, especially DC glaciers with lake which showed rapid ice mass melting rates, indicating the expansion and formation of lakes. Similarly glaciers near median elevation shrank noticeably, with decadal scale revealing the melting in surface area. In addition, the upward shift of ELA by $180 \mathrm{~m}$ during three decades also conduced to the fact of shrinking ice mass. However, glaciers at higher elevation change less significantly than those at lower elevation. The melting of the ice at steep slopes implies the current glacier condition resulted in a lessening of glacier numbers.

Glacier melting has a profound impact on water resources. The decreasing trend in glacier area will have direct impacts on ice storage and ultimately on glacier melt runoff. Temperature and precipitation are important factors that influence climatic variability, and analysis of such variables can model the potential future behavior of glaciers since $>65 \%$ of the monsoon-influenced glaciers that have been observed are retreating (Scherler and other, 2011). Adding the conservative scenarios of glacierized area and meltwater flux has shown variation in numerous glacierized regions of the Himalaya by monsoon (Rupper and others, 2012). However, our study does not cover the influence of climatic factors; instead it provides significant investigations of glacier change scenarios on a decadal scale, which acts as a baseline for observing and monitoring future glacier health and its dynamics.

\section{CONCLUSION}

We have provided a comprehensive picture of the status of glaciers and its decadal change ( 1980 to 2010) in the Bhutan Himalaya, based on multitemporal Landsat images and a SRTM DEM. A semi-automatic object-based classification was used to generate glacier outlines for 2010. The repeat glacier outlines were made for 2000, 1990 and 1980 based on manual editing on the baseline glacier of 2010. Analysis of the four-decade glacier data shows rapid shrinkage in recent decades, with the highest decrease in smaller glaciers. The major findings of the study include:

1. Archiving of repeat decadal glacier inventory of Bhutan from 1980 to 2010 based on Landsat images;

2. The glacier area loss in Bhutan from $\sim 1980$ to 2010 was $23.3 \pm 0.9 \%$, with a trend of $-6.39 \pm 1.6 \%(10 a)^{-1}$;

3. The shrinking and fragmentation of glaciers from $\sim 1980$ to 2010 resulted in an increase in the number of glaciers by $14.8 \%$;

4. The rate of reduction of glacier area in different elevation zones varies: glaciers at elevations of 5500-5200 ma.s.l. are receding faster, except where the glacier ice is covered by debris;

5. The ELA has shifted from $5170 \pm 110$ ma.s.l. to $5350 \pm$ 150 m a.s.l. in the years $\sim 1980$ to 2010 .
6. The retreat rate of DC glaciers with a glacial lake at the snout is higher than that of DC glaciers without a lake, the best example being in the Lunana region.

Glacier area in the Bhutan Himalaya is rapidly changing. The Landsat data provide an ideal tool to understand the status of and changes on glaciers, at least for the last 30 years.

The glacier data of Bhutan will be uploaded in the ICIMOD mountain geo-portal (http://geoportal.icimod.org) and will later be ingested into the GLIMS and Randolph Glacier Inventory websites.

\section{ACKNOWLEDGEMENTS}

We are grateful to Basanta Shrestha, Division Head of MENRIS (Mountain Environment and Natural Resources Information Systems, Kathmandu), for his constant guidance, inspiration and support. The study was supported by HIMALA and SERVIR Himalaya of NASA and the United States Agency for International Development (USAID). Landsat data are courtesy of NASA and the USGS. The SRTM elevation model version is courtesy of NASA's Jet Propulsion Laboratory and was further processed by the Consultative Group for International Agriculture Research (CGIAR). The glacier database was generated with the support of the Cryosphere Monitoring Project of the Swedish International Development Cooperation Agency and the Norwegian Ministry of Foreign Affairs.

\section{REFERENCES}

Arendt A and 78 others (2013) Randolph Glacier Inventory: a dataset of global glacier outlines: version 3.2. Global Land Ice Measurements from Space, Boulder, CO. Digital media http:// www.glims.org/RGI/randolph.html

Bajracharya SR and Mool P (2009) Glaciers, glacial lakes and glacial lake outburst floods in the Mount Everest region, Nepal. Ann. Glaciol., 50(53), 81-86 (doi: 10.3189/172756410790595895)

Bajracharya SR and Shrestha B (2011) The status of glaciers in the Hindu Kush-Himalayan region. International Centre for Integrated Mountain Development, Kathmandu

Bajracharya SR, Mool PK and Shrestha B (2007) Impact of climate change on Himalayan glaciers and glacial lakes: case studies on GLOF and associated hazards in Nepal and Bhutan. (ICIMOD Publication 169) International Centre for Integrated Mountain Development and United Nations Environment Programme Regional Office, Asia and the Pacific, Kathmandu

Basnett S, Kulkarni AV and Bolch T (2013) The influence of debris cover and glacial lakes on the recession of glaciers in Sikkim Himalaya, India. J. Glaciol., 59(218), 1035-1046 (doi: 10.3189/ 2013JoG12J184)

Beedle MJ and 7 others (2008) Improving estimation of glacier volume change: a GLIMS case study of Bering Glacier System, Alaska. Cryosphere, 2(1), 33-51 (doi: 10.5194/tc-2-33-2008)

Bhambri R and Bolch T (2009) Glacier mapping: a review with special reference to the Indian Himalayas. Progr. Phys. Geogr., 33(5), 672-704 (doi: 10.1177/0309133309348112)

Bolch T and Kamp U (2006) Glacier mapping in high mountains using DEMs, Landsat and ASTER data. Grazer Schr. Geogr. Raumforsch. 41, 13-24

Bolch T, Buchroithner MF, Kunert A and Kamp U (2007) Automated delineation of debris-covered glaciers based on ASTER data. In Gomarasca MA ed. Geolnformation in Europe. Proceedings of the 27th EARSel Symposium, 4-6 June 2007, Bolzano, Italy. Millpress, Rotterdam, 403-410

Bolch T, Buchroithner M, Pieczonka T and Kunert A (2008) Planimetric and volumetric glacier changes in the Khumbu 
Himal, Nepal, since 1962 using Corona, Landsat TM and ASTER data. J. Glaciol., 54(187), 592-600 (doi: 10.3189/ 002214308786570782)

Bolch T, Menounos B and Wheate R (2010) Landsat-based inventory of glaciers in western Canada, 1985-2005. Remote Sens. Environ., 114(1), 127-137 (doi: 10.1016/j.rse.2009.08.015)

Bolch T and 11 others (2012) The state and fate of Himalayan glaciers. Science, 336(6079), 310-314 (doi: 10.1126/ science.1215828)

DeBeer CM and Sharp MJ (2007) Recent changes in glacier area and volume within the southern Canadian Cordillera. Ann. Glaciol., 46, 215-221 (doi: 10.3189/172756407782871710)

Frey $\mathrm{H}$ and Paul F (2012) On the suitability of the SRTM DEM and ASTER GDEM for the compilation of topographic parameters in glacier inventories. Int. J. Appl. Earth Obs. Geoinform., 18, 480-490 (doi: 10.1016/j.jag.2011.09.020)

Frey H, Paul F and Strozzi T (2012) Compilation of a glacier inventory for the western Himalayas from satellite data: methods, challenges and results. Remote Sens. Environ., 124, 832-843 (doi: 10.1016/j.rse.2012.06.020)

Fujita K (2008) Effect of precipitation seasonality on climatic sensitivity of glacier mass balance. Earth Planet. Sci. Lett., 276(1-2), 14-19 (doi: 10.1016/j.epsl.2008.08.028)

Fujita K, Kadota T, Rana B, Kayastha RB and Ageta Y (2001) Shrinkage of Glacier AX010 in Shorong region, Nepal Himalayas in the 1990s. Bull. Glaciol. Res., 18, 51-54

Hall DK, Bayr KJ, Schöner W, Bindschadler RA and Chien JYL (2003) Consideration of the errors inherent in mapping historical glacier positions in Austria from ground and space (1893-2001). Remote Sens. Environ., 86(4), 566-577 (doi: 10.1016/S00344257(03)00134-2)

Hendriks JPM and Pellikka P (2007) Semi-automatic glacier delineation from Landsat imagery over Hintereisferner in the Austrian Alps. Z. Gletscherkd. Glazialgeol., 41, 55-75

Komori J (2008) Recent expansions of glacier lakes in the Bhutan Himalayas. Quat. Int., 184(1), 177-186

Kulkarni AV and 6 others (2007) Glacial retreat in Himalaya using Indian remote sensing satellite data. Curr. Sci., 92(1), 69-74

Meyer MC, Hofmann C-C, Gemmell AMD, Haslinger E, Häusler H and Wangda D (2009) Holocene glacier fluctuations and migration of Neolithic yak pastoralists into the high valleys of northwest Bhutan. Quat. Sci. Rev., 28(13-14), 1217-1237 (doi: 10.1016/j.quascirev.2008.12.025)

Mool PK, Wangda D, Bajracharya SR, Kunzang K, Gurung DR and Joshi SP (2001a) Inventory of glaciers, glacial lakes and glacial lake outburst floods: monitoring and early warning systems in the Hindu Kush-Himalayan region, Bhutan. International Centre for Integrated Mountain Development with United Nations Environment Programme/Regional Resource Centre for Asia and the Pacific, Kathmandu

Mool PK, Bajracharya SR and Joshi SP (2001b) Inventory of glaciers, glacial lakes and glacial lake outburst floods: monitoring and early warning systems in the Hindu Kush-Himalayan region, Nepal. International Centre for Integrated Mountain Development with United Nations Environment Programme/Regional Resource Centre for Asia and the Pacific, Kathmandu

Paul F and Andreassen LM (2009) A new glacier inventory for the Svartisen region, Norway, from Landsat ETM+ data: challenges and change assessment. J. Glaciol., 55(192), 607-618 (doi: 10.3189/002214309789471003)

Paul F and Kääb A (2005) Perspectives on the production of a glacier inventory from multispectral satellite data in Arctic
Canada: Cumberland Peninsula, Baffin Island. Ann. Glaciol., 42, 59-66 (doi: 10.3189/172756405781813087)

Paul F, Kääb A, Maisch M, Kellenberger T and Haeberli W (2002) The new remote-sensing-derived Swiss glacier inventory: I. Methods. Ann. Glaciol., 34, 355-361 (doi: 10.3189/ 172756402781817941)

Paul F, Huggel C and Kääb A (2004) Combining satellite multispectral image data and a digital elevation model for mapping debris-covered glaciers. Remote Sens. Environ., 89(4), 510-518 (doi: 10.1016/j.rse.2003.11.007)

Paul F and 19 others (2013) On the accuracy of glacier outlines derived from remote-sensing data. Ann. Glaciol., 54(63 Pt 1), 171-182 (doi: 10.3189/2013AoG63A296)

Rabatel A, Dedieu J-P and Vincent C (2005) Using remotesensing data to determine equilibrium-line altitude and mass-balance time series: validation on three French glaciers, 1994-2002. J. Glaciol., 51(175), 539-546 (doi: 10.3189/ 172756505781829106)

Rabatel A and 7 others (2012) Can the snowline be used as an indicator of the equilibrium line and mass balance for glaciers in the outer tropics? J. Glaciol., 58(212), 1027-1036 (doi: 10.3189/ 2012JoG12J027)

Rabatel A, Letréguilly A, Dedieu J-P and Eckert N (2013) Changes in glacier equilibrium-line altitude in the western Alps from 1984 to 2010: evaluation by remote sensing and modeling of the morpho-topographic and climate controls. Cryosphere, 7(5), 1455-1471 (doi: 10.5194/tc-7-1455-2013)

Racoviteanu AE, Williams MW and Barry RG (2008) Optical remote sensing of glacier characteristics: a review with focus on the Himalaya. Sensors, 8(5), 3355-3383 (doi: 10.3390/ s8053355)

Racoviteanu AE, Paul F, Raup B, Khalsa SJS and Armstrong R (2009) Challenges and recommendations in mapping of glacier parameters from space: results of the 2008 Global Land Ice Measurements from Space (GLIMS) workshop, Boulder, Colorado, USA. Ann. Glaciol., 50(53), 53-69 (doi: 10.3189/ 172756410790595804)

Raup B, Racoviteanu A, Khalsa SJS, Helm C, Armstrong R and Arnaud Y (2007) The GLIMS geospatial glacier database: a new tool for studying glacier change. Global Planet. Change, 56(1-2), 101-110 (doi: 10.1016/j.gloplacha.2006.07.018)

Ren J, Jing Z, Pu J and Qin X (2006) Glacier variations and climate change in the central Himalaya over the past few decades. Ann. Glaciol., 43, 218-222 (doi: 10.3189/172756406781812230)

Rupper S, Schaefer JM, Burgener LK, Koenig LS, Tsering K and Cook ER (2012) Sensitivity and response of Bhutanese glaciers to atmospheric warming. Geophys. Res. Lett., 39(19), L19503 (doi: 10.1029/2012GL053010)

Scherler D, Bookhagen B and Strecker MR (2011) Spatially variable response of Himalayan glaciers to climate change affected by debris cover. Nature Geosci., 4(3), 156-159 (doi: 10.1038/ ngeo1068)

Silverio W and Jaquet J-M (2005) Glacial cover mapping (1987-1996) of the Cordillera Blanca (Peru) using satellite imagery. Remote Sens. Environ., 95(3), 342-350 (doi: 10.1016/ j.rse.2004.12.012)

Vohra CP (2010) Glaciers of India - a brief overview of the state of glaciers in the Indian Himalaya in the 1970s and at the end of the 20th century. In Williams RS Jr and Ferrigno JG eds. Satellite image atlas of glaciers of the world - glaciers of Asia. (US Geological Survey Professional Paper 1386-F-5) US Geological Survey, Reston, VA, F259-F274 